Stellenbosch Theological Journal 2017, Vol 3, No 1, 515-545

DOI: http://dx.doi.org/10.17570/stj.2017.v3n1.r01

Online ISSN 2413-9467 | Print ISSN 2413-9459

2017 @ P Pieter de Waal Neethling Trust

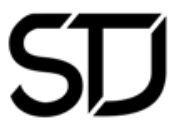

\title{
Why faith makes sense: On Graham Ward's Unbelievable
}

\author{
Delport, Khegan M \\ Stellenbosch University \\ khegan.delport@gmail.com
}

\begin{abstract}
Ward's recent volume on the entwining of belief and perception, while not being an explicitly theological monograph, nonetheless evinces a subtle texture that displays his continuing fidelity to certain aspects of Radical Orthodoxy's vision. (Ward, Graham 2013. Unbelievable: Why We Believe and Why We Don't. London and New York: I. B. Tauris; ISBN: 971780767352)

This can be seen in its interdisciplinary focus and its rejection of dualistic philosophies (including the supposed divisions between the sacred and the secular, nature and grace, transcendence and immanence, visibility and invisibility). He argues for the ultimate 'fittingness' between mind and world, thereby rejecting any representationalist account of this relation. Viewing the practices of belief within a re-telling of evolutionary history and phenomenological accounts of perception, Ward seeks to show the pervasiveness of dispositional beliefs within all worldly interactions. Consequentially, 'belief' cannot therefore be relegated to an epiphenomenal or lesser form of knowing, since all seeing is a seeing-as, with the result being that it is imbued with the valences of affect and valuation. Religious faith then is simply a deepening of the logic that is already present within ordinary modes of finite engagement, and therefore should not be seen as an 'unnatural' intervention within the realm of human culture. Overall then, this work can be summarized as an apologetic for the rationality of belief in our 'secularized' societies, and furthermore, for the constitutive role of belief and faith for sensibility as such.
\end{abstract}

We believe without belief, beyond belief (Wallace Stevens) ${ }^{1}$

Credo ut Intelligam. This dictum of Augustine and Anselm could serve justly as a dilution of Graham Ward's central contention in this monograph. He himself summarizes his position in similar terms towards the end of

1 'Flyer's Fall' in Collected Poems (London: Faber and Faber, 1984), p. 294. 
the book: 'I believe in order that I may know' (p. 219), a statement that encapsulates his contention that belief is necessary for any perception of reality itself. To be sure, his reading public are not assumed to be the theologically literate, or even the religiously devout. But one can nonetheless read the trajectory of his argument as cohering with other projects of like-minded thinkers, who contend that without 'religious' sentiments of some kind - however subliminal or nascent - the world of phenomena is rendered dubious, gnoseologically-speaking. A sample of comparative projects would include Jean-Louis Chrétien's blending of phenomenology and theological conjecture ${ }^{2}$, or Rowan Williams' attempt to understand the creative instincts ${ }^{3}$ and language ${ }^{4}$ within the rubrics of grace and 'givenness'. Additionally, one could mention John Milbank's denial of any coherent notion of human sociality ${ }^{5}$ or the world of things ${ }^{6}$ that lacks a theological dimensionality, as well as Catherine Pickstock's reflections on the relation between ritualized liturgy and the construction of sensibility. ${ }^{7}$ Ward does not explicitly place his argument within this developing tradition, but the inherent grammar of his argument makes substantial links to such styles of thought.

As can be seen, the given title of this review deliberately plays upon the double meaning inherent in the language of 'making sense'. The idiomatic usage implies reference to the reasonable and the 'commonsensical', thereby invoking the often-unreflective, intuitive sensation of harmony within the realm of human communication and understanding (a tradition stemming

2 Jean-Louis Chrétien, The Call and the Response, trans. Anne Davenport (New York: Fordham University Press, 2004).

3 Rowan Williams, Grace and Necessity: Reflections on Art and Love (London and Harrisburg: Continuum, 2005).

4 Rowan Williams, The Edge of Words: God and the Habits of Language (London: Bloomsbury, 2014).

5 John Milbank, Theology and Social Theory: Beyond Secular Reason (2 ${ }^{\text {nd }}$ ed. Oxford: Blackwell, 2006).

6 John Milbank, 'The Thomistic Telescope: Truth and Identity,' American Catholic Philosophical Quarterly 80, no. 2 (2006): 193-226.

7 C. J. C. Pickstock, 'The Ritual Birth of Sense,' Telos 162 (Spring 2013): 29-55.

8 For a philosophical genealogy of the various notions of 'sense', see Fabienne Brugère, 'Common Sense'; Barbara Cassin, Sandra Laugier, Alain de Libera, Irène Rosier-Catach and Giacinta Spinosa, 'Sense / Meaning'; Alain De Libera, 'Sensus Communis,' in Dictionary of Untranslatables: A Philosophical Lexicon, ed. Barbara Cassin (Princeton and Oxford: Princeton University Press, 2014), pp. 152-154; 949-967; 967-968 resp. 
from Shaftesbury, Reid, and Hume). In this register, 'making sense' is equated with the order of rationality and the common good, as when we say, for example, that a certain idea 'makes sense' or is 'sensible'. In Ward's argument, the outworking of this usage lies within his tacit apologetics for the general category of 'belief' and 'faith' against the claims of a 'mythical' secularism which seeks to assert the public irrationality and decline of religious discourse and practice (pp. 161-186). ${ }^{9}$ However, a more radical interpretation of this phrase can be given, one that seems to be foundational for Ward's contention: namely, that it is precisely the category of belief itself (as a perceptive disposition ${ }^{10}$ ) that makes possible our faculties of 'common sensation' (to use an Aristotelian phrase). It is the 'dispositional space' of belief (to reference Antonio Damasio) that makes the construction of 'meaning' fundamentally achievable (pp. 98-99, and passim). To see anything is always a determinate seeing-as (as Ward reiterates frequently) so that what is seen and sensed is never blandly neutral or 'objective' but rather is disposed and perspectival. Such dispositional frameworks largely exist in inchoate forms, and it takes conscious reflection to be aware that we are operating within the arena of such non-thematised beliefs.

And so it is Ward's task in this monograph to manifest how such processes of belief are embodied within human evolution and culture, a journey that takes us from the mysterious portals of Qafzeh, Chauvet and Shanidar, to the literary forays of Graham Greene's Brighton Rock, reaching eventually the speculations of French phenomenology. Such a grounding makes this book Ward's most interdisciplinary work to date, and (much like Conor Cunningham's Darwin's Pious Idea ${ }^{11}$ ) shows that there is a growing tendency, within the broad Radical Orthodoxy movement, towards embracing this kind of work (further belying the contention of erstwhile critics that the movement displays a wanton insularity). Such interdisciplinary, in a

9 Also cf. Graham Ward, 'The Myth of Secularism,' Telos 167 (Summer 2014): 162-79.

10 Ward describes his understanding of belief as disposition in the following manner: 'I am defining 'belief...as a disposition....and while belief can be conscious, even rationally justified through a degree of reflective critique, it is not solely conscious. Preconscious belief is then an implicit knowledge. I call it a 'disposition' because, as a form of behaviour, its orientation is 'eccentric' - it looks beyond the individual who believes toward some object or person or condition in the world. It is 'disposed towards' as basic evolution is disposed towards survival and reproduction' (Unbelievable, pp. 29-30).

11 Conor Cunningham, Darwin's Pious Idea: Why Ultra-Darwinists and Creationists Both Get It Wrong (Grand Rapids: Eerdmans, 2010). 
comparable manner to its position on the theology-philosophy kinship, seems to be based on the generously 'Catholic' ideas of the analogia entis and the Thomistic accounts of grace, whereby the natural and finite order is believed to opaquely intuit and disclose, in a non-finalised manner, the ontological truth of things. In this perspective, the super-addition of grace is seen to have a certain 'fittingness' (convenientia) in relation to the economy of created being. This factor (as Ward's recent work shows) is basic to his practice of an 'engaged systematics'12 that seeks to relate the 'porosity'13 of life to theological reasoning in general, overcoming the often presupposed 'dualisms' that falsely bifurcate the divisions of intellectual labour. One also suspects that the diffused theological culture of 'incarnationalism' within Anglo-Catholic thinking has done its work here, a trend that manifests itself in Ward's previous orientations towards 'embodiedness' and questions of gender, and appears now in his interactions with the realm of the neurosciences and evolutionary biology, as well as his recent emphasis on the psychology of affectivity. ${ }^{14}$ As Ward says towards the conclusion of the monograph: 'belief incarnates and is always incarnational' (p. 220).

The subtitle of the book gestures towards the central question which Ward's argument aims to explore, namely the varying factors that contribute to the structures of belief. There are three questions which Ward seeks to answer: (i) What makes a belief? (ii) What makes belief believable? (iii) What makes a belief believable? Regarding the first question, it should said that belief is understood to have least two levels of operation: (1) belief as the primordial disposition of seeing-as which operates as a mode of 'liminal processing' that 'thinks' and 'reacts' more 'instinctively than our conscious rational deliberation' (p. 12). Such beliefs are prior to and deeper than instrumental and causal notions of 'reasons for' (p. 13). In addition to this notion, (2) belief can be understood as a conscious and 'specific commitment' that manifests itself in varying forms of religious faith and choate forms of believing (p. 219).

12 Graham Ward, How the Light Gets In: Ethical Life I (Oxford: Oxford University Press, 2016), pp. 115-144.

13 This language is drawn from Sarah Coakley, God, Sexuality, and the Self: An Essay 'On the Trinity' (Cambridge: Cambridge University Press, 2013), pp. 33-65.

14 Graham Ward, 'Affect: Towards a Theology of Experience,' Radical Orthodoxy: Theology, Philosophy, Politics 1, no. 1-2 (2012): 55-80; Ward, 'Salvation: The Pedagogy of Affect,' Nederduits Gereformeerde Tydskrif Supplement 1 (2014): 999-1013. 
The second question regards the issue of believability, and relates to the realm of culture and history, and how these impact the spheres of 'mental imaging, intention, perception, judgement, image-making, knowledge, sense of the self and others as agents, and relations of trust or distrust with respect to agency'. All of these are 'an integral part of numerous forms of symbolic action', but they are also involved in 'the production and dissemination of ideology' (p. 15). The impact of cultural imagination on belief's believability is pivotal for Ward's argument: interpretation invades all our evaluations, which complicates the modern 'hierarchical' distinction between 'belief' and 'knowledge', 'interpretation' and 'evidence'. The importance of the 'the hermeneutical turn' is here clearly admitted by Ward, with critical theorists such as Anderson, Bourdieu, Castoriadis, and Certeau being commandeered for support in this regard (the last mentioned being particularly important ${ }^{15}$ ). Ward also references Kant's famous distinction between phenomena and noumena with the aim of articulating the point that we cannot know things in themselves, since we only perceive something as something, and therefore can make an 'approach' towards such knowledge, without necessarily ever 'having' such knowledge (pp. 16-17; also cf. pp. 214-215).

Before passing on, it does seem that some critical notice should be given to Ward's reference to Kant. Kant's phenomenalism is by no means an uncontroversial contention, and his distinction between phenomena and noumena is particularly worrisome. How can one assert dogmatically that we cannot know things-in-themselves without constructing a limit that predetermines what can and cannot be known. ${ }^{16}$ Does this not already presuppose where the one ends and the other begins? And when this is combined with Ward's broadly post-Husserlian framework ${ }^{17}$ one wonders

15 Also cf. Ward, How the Light Gets In, pp. 255-285 for a summary of his arguments on believability, and a more in-depth treatment of Certeau's notions of belief. Certeau's own positions can be found in Michel de Certeau The Mystic Fable: The Sixteenth and Seventeenth Centuries, vol. 1, trans. Michael B. Smith (Chicago: Chicago University Press, 1995) and Certeau, The Possession of Loudun, trans. Michael B. Smith (Chicago: Chicago University Press, 2000).

16 Cf. Constantino Esposito, „Die Schranken der Erfahrung und die Grenzen der Vernunft: Kants Moraltheologie“. Aufklärung 21 (2009): 117-145.

17 To be sure, I am not saying that Ward position fully coheres with the Husserl's brand of phenomenology (as he makes clear, his own position is more in line with the projects of Chrétien and Merleau-Ponty). However, in light of the Kantian presuppositions of 
if Ward is not giving sway to a certain Kantian apophaticism whereby the Ding-an-Sich (or Husserlian epoché) is considered to have an analogous function to the Thomistic notion of esse. ${ }^{18}$ Such Kantian 'negative theology' has been espoused by Donald MacKinnon ${ }^{19}$ and Paul Janz ${ }^{20}$, but has been criticized as having 'dogmatist' assumptions regarding the possible surveillability of metaphysical limits. ${ }^{21}$ It should be said that these are not major criticisms, but it does seem that Ward would have to clarify his position on Kant a bit further.

The third question ('What makes a belief believable?') relates to 'the conscious social production of belief' which is aligned with 'the deployments of power' in the 'social 'imaginary" (p. 18). In accordance with Bourdieu's notion of belief as 'symbolic capital'22, Ward argues that

The social imaginary and the cultural competition for value are both founded upon making what might be believed believable by any number of other people. To make any set of ideas about the world believable means winning support, and therefore the social and cultural resources accorded such support (p. 20).

Husserl's model, Ward's invocation here of Kant is not surprising. But it should be said that Ward elsewhere does have some critical things to say regarding the practices of phenomenological reduction. On this point, one could consult Graham Ward, 'The Logos, the Body and the World: On the Phenomenological Border,' in Transcending Boundaries in Philosophy and Theology, eds. Kevin Vanhoozer and Martin Warner (Aldershot and Burlington: Ashgate, 2007), pp. 105-126.

18 On Thomistic esse, see Josef Pieper, The Silence of St. Thomas: Three Essays (London: Faber \& Faber, 1957); John Milbank and Catherine Pickstock, Truth in Aquinas (London and New York: Routledge, 2001); Gilbert Narcisse, O.P. 'Thomistic Realism?' Nova et Vetera, English Edition 8, no. 4 (2010): 783-798.

19 Donald MacKinnon, 'Kant's Agnosticism,' in Philosophy and the Burden of Theological Honesty: A Donald MacKinnon Reader, ed. John McDowell. (London and New York: T \& T Clark, 2011), pp. 27-34; MacKinnon, 'Kant's Philosophy of Religion,' Philosophy 50, no.192 (1975): 131-144.

20 Paul D. Janz, God, the Mind's Desire: Reference, Reason and Christian Thinking (Cambridge: Cambridge University Press, 2004), pp. 123-167.

21 John Milbank, 'A Critique of the Theology of Right,' in The Word Made Strange: Theology, Language, Culture (Oxford: Blackwell 1997), pp. 7-35; Michael Hanby, 'Review: God, The Mind's Desire: Reference, Reason and Christian Thinking by Paul D. Janz,' Modern Theology 22, no. 2 (2006): 307-309.

22 Pierre Bourdieu, 'The Production of Belief: Contribution to an Economy of Symbolic Goods,' in The Field of Production: Essays on Art and Literature, ed. Randal Johnson (New York: Columbia University Press, 1993), pp. 74-111. 
The sociological observation that the phenomena of varying beliefs is related to questions of power and cultural dynamics within human society is here a largely descriptive enterprise. As is clear, Ward is not making a claim for any particular belief-system, but merely taking notice of the various requirements needed for any specific item of cultural capital to achieve wide-spread recognition. It is a question we shall turn to later, but there does seem to be a lack of clarity here regarding the criteria for discernment in adjudicating amongst competing belief-systems within this work. It will be argued later in this review that there are some potential criteria which can be so extracted from this work, but they are not systematically delineated. Clearly, Ward is attempting - in light of his potentially noncommitted audience - to appeal to a broad base of intellectual consensus, without making his argument dependent upon one specific instance of belief. However, by leaving questions of judgement and truth open-ended in this manner, there is a risk that the proliferations and productions of 'belief' are merely associated with the flux of cultural influence, thereby leaving open the possibility of a rather cynical conclusion being taken on the importance of any particular faith, or belief in general. To put it bluntly: 'believability' could be read here as merely the product of a certain will-to-power, one that is particularly congenial to our so-called 'post-truth' contexts and the continuing production of 'hyper-reality' and 'simulation'23. This is certainly not Ward's intention, as can be seen (for example) in his tirades on the incoherence of secularism, and on the importance of a committed, politicized Christian discipleship within the context of 'post materialism'. ${ }^{24}$ However, without clearly announcing the criteria for discerning such a hierarchy of beliefs, there is the risk of such a conclusion being made by the reader.

Underlying Ward's account of belief is Socrates' famous allegory of the cave $^{25}$ : as the sun casts shadows in the visible world, so the Good gives forth its own intelligible 'images' within the realm of sense. These 'images' are

23 Guy Debord, The Society of the Spectacle, trans. Ken Knabb (London: Rebel Press, 1992); Jean Baudrillard, Simulations, trans. Phil Beitchman et al. Semiotext[e] (Cambridge: MIT Press, 1983).

24 Graham Ward, The Politics of Discipleship: Becoming Postmaterial Citizens (Grand Rapids: Baker Academic, 2009).

25 Plato, Republic 514a-520a. 
grasped via the exercise of 'opinion' (pistis) and 'reason' (dianoia), which involve us in the progressive unveiling of these invisibilities within the material spheres of life: '[O]ur living with and among the material objects of the visible world will always mean that we live in the realm of belief' (p. 24). This exercise of 'reason' is processional and ever-deepening since it always remains 'incomplete', 'intentional' and thereby 'directed somewhere': 'It is 'about' something' (p. 24) and participates in an 'end-directed or teleological scheme of coming to know' (p. 25). Belief is therefore pervasive in our interaction with the world, and does not have to be overtly 'religious':

[B]elief itself, though perhaps orientated towards...transcendence, has a reality and a function with respect to knowing, being and doing that need not be associated with religion. Believing would be an important and constitutive aspect in the process of coming to know, in the operation of reason and in the pursuit of intelligence (p. 27).

Important for Ward's project here is to show how these processes of beliefformation are inscribed within the exigencies of evolution and biological development (since mind and matter here are not construed in a Cartesian fashion $\left.{ }^{26}\right)$. The fact that we are forward-moving, forward-looking hominids who are able to survey our environments from an upright position, combined with our greater sensitivity regarding touch and hand-use, is the basis for the elevated intelligence of homo sapiens (a point already intuited by Aristotle ${ }^{27}$ ). This intelligence is not primarily manifest in the choate and explicit formulations of one's world-relation, but can be seen in the more subtle and implicit movements of 'proprioception' (Raymond Tallis) in which 'sensing, evaluating and making sense' are 'earlier than cognitive perception as such' (p. 31). This is linked to the use of the hand as a 'somatic tool' (and tool-making in general), which assists in the gradual modulation towards what has been called 'prefontalization' (Terrence Deacon) in the neocortical lobes of the brain. This progress in braindevelopment leads eventually to the emergence of the homo symbolicus,

26 For more on this point, one could consult the excellent summary contained in Thomas Fuchs, 'Overcoming Dualism,' Philosophy, Psychiatry, \& Psychology 12, no. 2: 115-117.

27 On this point, see 'Body and Touch' in Chrétien, The Call and the Response. One could also consult John Milbank, 'The Soul of Reciprocity, Part Two: Reciprocity Granted,' Modern Theology 17, no. 4 (2001): 485-507. Ward himself has also made some contributions on this point in 'The Logos, the Body and the World: On the Phenomenological Border'. 
the advent of the linguistic animal (pp. 33-36). Here the concept of 'intentionality' comes to the fore, an idea of fundamental importance for palaeoanthropology, as can be seen in Ward's reference to the discovery of ancient burial sites in Shanidar, Qafzeh, and Atapuerca. These are not isolated occurrences, since the construction of hand-axes, arrow-heads, cave paintings, and sign-making in general are inexplicable without some notion intentionality amongst early hominids. These practices and rituals, as intentional activities, display the presence of 'creative consciousness, forward planning, instrumental reasoning and shared understanding' ( $\mathrm{p}$. 44). But beyond mere archaeological interest, Ward's usage of the concept of 'intention' has a deeper philosophical place in his thinking, since, as is well-known, it has been an important doctrine for post-Brentanian accounts of phenomenology. ${ }^{28}$ Ward particularly wants to emphasize how notions of anticipation (in hominids) are inextricably bound with notions of projection and perception, and therefore are tied to the realms of imagination and memory

Anticipation and projection require both cognitive abstraction from a set of changing conditions, rules for how things work in the world (based on how those things have worked in the past) and also the instrumental application of these abstractions to construct multiple, coexisting representations of 'what could happen'. Belief is evident not only in these projected possibilities - the belief of their possibility based on previous occurrences which are not simply recalled in order to predict. It also determines how what is seen is seen. Furthermore, belief also resides in the abstraction process itself - the construction of how things work in the world (pp. 48-49).

Other apes might be able to anticipate and interact intelligently with their environment, or make associations through repetitive training and habituation, but it is only hominids who can 'freely associate' by making 'inferential' judgements and associations between disparate items in their given milieu (p. 49). This ability to make intuitive connections is also tied to our ability to communicate and socialize, to engage in 'recognition'

28 On Husserl's account of intentionality and its intellectual genealogy, see André De Muralt, 'The 'Founded Act' and The Apperception of Others: The Actual Scholastic Sources of Husserlian Intentionality. An Essay in Structural Analysis Of Doctrines,' in Analecta Husserliana: The Yearbook Of Phenomenological Research, vol. VI, ed. AnnaTeresa Tymieniecka (Dordrecht: Springer, 1977), pp. 123-141. 
whereby 'from a consciousness of myself I come to an understanding of the other, myself and the relation of meaning binding both other and self' ( $p$. 53). This forms the basis for a 'sharing' and 'trust' in 'a process of knowing' that is 'emotional and relational before it is rational'. Thus, Ward argues that, fundamentally, 'Belief is a relational category' (p. 55).

Such capacity to make connections and inferences from seemingly discrete items in our world - what one could call our 'poetic' capacity ${ }^{29}$ - combined with our aptitude to form relational and epistemic ties to such realities, is the entrance into religious and metaphysical speculation, in which we make 'an inner association between the interiority of belief, the wonder, the love, the investment of oneself in the meaningfulness of what is other and exterior, the dwelling and sense that one belongs, and religion'. These capacities establish the basis for the experiences of 'transcendence' and 'primordial givenness', opening us to the receptive qualities of 'discovery', 'disclosure', and 'creation' (p. 57).

For Ward religion, and therefore religious faith, emphasises the discovery and the disclosure: it is the world that is meaningful, ordered, and structured as accommodating to human apprehension. Belief makes no such semantic claim: it allows for the creation of what is meaningful, it informs the way we see the world as, but the world may not be intrinsically meaningful. There may not be meaning 'out there' - nevertheless, because of belief, we who dwell within the world and respond to it will make it meaningful for us (p. 58).

This prompts Ward to engage with some of the neuroscientific and archaeological research done in relation the birth of religious imagination and consciousness. Here Ward relies strongly on the work of Steven Mithen and David Lewis-Williams, particularly as it relates to altered states of consciousness. In these states, one encounters 'the uncanny' in which 'believing is accentuated because the stability of what is perceived - which is stable only because it is in accord with what is familiar, the recognition of which has become habitual - is disturbed' (p. 61). The consciousness

29 See John Milbank, 'On the Diagonal: Metaphysical Landscapes,' in The Legend of Death: Two Poetic Sequences (Eugene, Oregon: Cascade Books, 2008), pp. 2-7. Also, cf. Rowan Williams, 'Poetic and Religious Imagination,' Theology 80 (1977): 178-187; J. H. Prynne, Stars, Tigers and the Shape of Words (London: Birkbeck, 1993), and Prynne, 'Poetic Thought,' Textual Practice 24, no. 4 (2010): 595-606. 
is disturbed because its tendency is towards 'holism' in the sense that it works 'to cut, paste, edit and delete in order to present a single stream' (p. 66). Important for Ward here is the analysis of consciousness that lies behind the practice and rituals of cave paintings in which our Palaeolithic ancestors habitually immersed themselves. These investigations show that religion lies at the genesis of human consciousness and its interaction with the world, though we cannot speak for certain of an exact coincidence of these realities. Ward is critical here of Lewis-Williams since he attempts to understand the archive of religiously-oriented states of consciousness (in tension with some of Lewis-Williams' own stated presuppositions against Western forms of rationalism) in a scientifically 'reductive' manner. He seeks to explain the mythopoeic, metaphysically textured drama of Palaeolithic art to be nothing more than 'the electrochemical functioning of the brain' in which the 'magic' described therein is subordinated to 'the researches of cognitive-and neuroscience'.

For Ward, the assumed procedure of Lewis-Williams leads to the triumph of logos over mythos (p. 71) and so is simply one more attempt to banish the 'sacred' from the 'secular'. Instead, Ward suggests, firstly, that 'nature does not give rise unilaterally to culture. There is co-evolution. Put simply: believing moulds the neural networks of the brain for belief...We don't just biologically adapt to our landscapes, we shape and impact upon those landscapes in ways which require us to readapt' (p. 72). This leads Ward to his second point (here echoing the language of the philosopher Wilfrid Sellars $\left.{ }^{30}\right)$ :

[I]n co-evolution the world is not simply the given to our senses such that our bodies become organic receptors of information. The objective and external nature of the given as such is a myth. The world is given, created, discloses itself to and affects us. It is through this impossible-to-divorce association of the inner workings of the body, the productions of the mind and the external environment that a certain fittingness or accommodation comes about (p. 73).

30 Regarding 'the myth of the given', see Wilfrid Sellars, 'Empiricism and the Philosophy of Mind,' in The Foundations of Science and the Concepts of Psychology and Psychoanalysis. Minnesota Studies in the Philosophy of Science, vol. I, eds. Herbert Feigl and Michael Scriven (Minneapolis: University of Minnesota Press, 1956), pp. 253-329. 
The above mentioned triumph of logos over mythos is part and parcel with certain tendencies in Western thinking to privilege a certain kind of brain 'lateralisation', namely left-hemisphere over right-hemisphere forms of thinking, as this relates respectively to the left and right lobes of the prefrontal cortex. Drawing upon the investigations of Iain McGilchrist, Ward attempts to show how the overemphasis on left-lateralisation has led to a suppression of the 'creative', 'intuitive', 'emotional', 'imaginative', 'relational' and 'big-picture' modes of thinking that are intrinsic to human awareness. Right brain thinking, rather than emphasising what is clear and analytically certain, aims towards more hazy and preconscious modes of world-relating. In this regard, McGilchrist mentions how the category of 'belief' has also suffered under this regime since it is often considered to be merely a weaker version of 'knowing', and therefore can be supplanted by more overtly rationalist modes of thought (p. 74-78).

Ward is thoroughly appreciative of McGilchrist's rejection of 'binarism' in relation to our study of the brain, but is critical of his characterisation of belief as an as if, in the sense that belief operates when we act as if certain realities were true for us. For Ward, this description of belief is 'condescending' (p. 79) since it implies that one can be placed on a metaphysical pedestal, thereby given the power to determine the verity of whether someone was acting as if what they believe were true. It also presupposes a certain 'Cartesian' (and Kantian) schema wherein belief is understood to be merely a matter of the monadic and voluntaristic 'choice' to act as if such-and-such an element were a truthful description of the world (pp. 79-80). However, despite these qualms, Ward continues to hold to the importance of McGilchrist's work, for the following reasons:

First, believing is not a weak form of knowing but a faithfulness to one's intuitions that will always remain somewhat inchoate, even if resonant with meaning, a right-hemisphere cognitive and affective activity. It is faithfulness to pursuing those intuitions, seeking to understand them; it makes religious faith possible (but not necessary). Secondly, modernity is driven by the need for true and certain knowledge discovered, measured and evaluated through instrumental reasoning that requires faster and increasingly more efficient forms of technology, bureaucracy and surveillance to filter our untruth and illusion...Thirdly, by cutting itself off 
from experiential grounding, concern for context and time, and caring and empathetic attentiveness of right-hemisphere activity, modernity increasingly generates an image of itself (upon which it increasingly reflects), convinced that what it views in the mirror of its representations is the truth about all that is. Hence in the staggering overproduction of simulacra and virtual realities, another form of believing emerges from this left-hemisphere tyranny that is not the same as the believing that issues from right-hemisphere activity (p. 83).

These discussions of 'lateralisation', 'intentionality' and the birth of various forms of 'imagination' (particularly 'religious' imagination) presuppose the datum of consciousness. In adherence to his rejection of dualistic accounts, Ward would want to emphasise that 'Consciousness emerges in some way from neural activity'; but moreover, he would want to stress that 'The important point...is that consciousness is not just a product of the neo-or cerebral cortex, but of the whole of the brain' ( $\mathrm{p}$. 87). Here he acknowledges the current scientific limits regarding the origins of consciousness or mind generally. (He rejects however the purely 'materialist' biases of figures such as Daniel Dennett since they often seem to presuppose the reality that they seek to explain. ${ }^{31}$ ) However, for Ward's purposes regarding belief and dispositions, the reality of consciousness is important since (to quote Dennett), 'Seeing is believing', meaning that perception itself involves intentional and dispositional characteristics which are irreducible: 'belief goes all the way down. All reality is virtual' (p. 89). Such intentionality is not an isolated phenomenon but is repeated, for example, within the 'teleodynamic tendencies' of cells (p. 91), which

31 'The accounts of mental processes as electrochemical transmissions of information rely upon metaphors often drawn from computing circuitry. The metaphorical nature of the discourses reveals the gap between physicality of the processing and the mental account whereby we come to an understanding of this processing. Such accounts then already go beyond the physical properties of the things they are defining. They involve ideas divorced in some ways from the processing; divorced because otherwise we would have to admit to mind, ideas, beliefs, causally effecting these processes - processes that, on these accounts, give rise to and are therefore the cause of mind, ideas, representations, etc....The irreducibility of belief to the physics and chemistry of the brain draws our attention to a lacuna that cannot be disassociated from the lacuna consciousness itself. We cannot fully account for belief, and belief cannot fully account for itself. We don't always (possibly most the time) know believing's secret operations, its secret selections among our memories, emotions and understandings' (Unbelievable, p. 112). 
could even be called 'teleosemantic' since 'intention' is 'manifest' in a 'purpose-driven meaningfulness' in which 'intention becomes a 'semantic' phenomenon (p. 92). Such an intention towards 'meaningfulness' (which occurs even at the cellular level) makes the human drive towards characterising and interpreting lived experience - the whole reality of 'mind' - less rhapsodic since it is placed within a physical context that has certain 'teleological' tendencies, within a wider network of signs and intentions that enact themselves within the seemingly 'mindless' or 'nonconscious' forms of material existence (a pattern that seems to buttress certain avant-garde attempts, philosophical and otherwise, to understand all of reality panpsychically - but more on that later).

The tendency towards meaningfulness, intelligibility and teleological ordering in the natural realm - a pattern already seen by figures such as Aristotle $^{32}$ - can be further supported by the reality of 'mirror-neurons' which Ward describes as 'neurons involved in imitative behaviour such that when I perceive and experience an external action my body and brain mimic, to some extent, that same activity'. For Ward, the activity of mirrorneurons are important for the 'biology of belief' since 'They write the 'as if ${ }^{33}$ of belief into our physiologies because they invoke the 'simulation, in the brain's body maps, of a body state that is not actually taking place in

32 Cf. Jonathan Lear, Aristotle: The Desire to Understand (Cambridge: Cambridge University Press, 1988).

33 There does seem to be a distinction here between Ward's use of 'as-if feeling states' and his earlier criticism of McGilchrist regarding belief as a conscious, as if - formulation of reality. The former refers to our more unconscious attempts to mimetically absorb external realities and to create intelligible patterns from them, while the latter does seem to exhibit a certain externalized perspective on belief as such since it presupposes, or seems to introduce, the idea of unreality into the notion of belief itself. One reads the world in a certain way even though one knows that such a reading is potentially wrong or dubious - one simply 'chooses' to see the world as if a certain reality were true, thereby suspending one's disbelief. It is this perspective which Ward describes as 'condescending' and 'sadomasochistic', invoking the example of Cypher in the Waschowski's sci-fi classic The Matrix (1999), in which Cypher willingly chooses to betray Zion (the revolutionary movement) in exchange for amnesiastically re-entering 'the Matrix', a virtual world created by machines to trick human beings into believing that they are living normally, while in reality their bodies are being harvested for energy production. In his meeting with the Agent (who represents a software version of the Gestapo or Stasi, designed to repress dissent), Cypher sits down for a meal and expresses his knowledge that the steak he is eating is not real, but nonetheless this manufactured reality was better than the alternative of living in the real world of struggle against the Matrix. It is this choice for 'unreality' over 'reality', this willful suspension of disbelief (or knowledge) which Ward considers to be 'sadomasochistic'. 
the organism' (Ward is here referencing the work of Giacomo Rizzolati and Antonio Damasio). Mirror-neurons show us that 'belief is not only embodied but inseparable from the capacity to imagine. The critical contents of the conscious mind are thereby organised' (p. 96). This propensity to organize and create analogous connections between experiences and memories is expounded by Ward in the following way:

The act of trying to 'absorb' the experiences and the time is [takes] for this 'absorption'... are products of higher-order thoughts and perceptions. The brain records the manifold consequences of the body's interaction with stimuli and the emerging sensimotor patterns seek associations with previous memories of comparative and analogous situations. Higher-order consciousness can only emerge from this activity, and the associating processes are highly selective since our 'memories are prejudiced, in the full sense of the term, by our previous history and beliefs ${ }^{\prime 34}$ (p. 97).

From this point, Ward moves on to a particularly good part of this monograph in his chapter entitled 'Sense and Sensibility: The Unbearable Lightness of Certainty' (which forms the first chapter in the second part of the book entitled 'Believability'). He speaks of how from early on

Human beings began living with the invisible while adapting themselves to a hundred different material landscapes. They accommodated themselves to the material in and through the immaterial. And this immateriality concerned not just gods, mythic animals, magic forces and inscrutable cosmic powers, but also the immateriality of ideas, stories, images and icons, some of which now were being stored and transmitted through symbolic representation. Our believing is now inseparable from this symbolic activity in which the natural and cultural drive forward our evolution, our civilization (p. 104).

These beliefs cannot be reduced to the 'purely' rational since they are laden with emotion and affect; they are self-involving realities and not merely the product of cold ratiocination. This embeddedness of beliefs in physical states, the permeation and confusion of the invisible within the orders of materiality, leads Ward to the question of the convenientia between mind

34 The quote is taken from Antonio Damasio. 
and matter, particularly as this focuses on 'the subjective experience of the world and the mind with respect to the world' (p. 107). It is here that Ward discusses the proposal of 'panpsychism' or 'neutral monism' ${ }^{35}$ which Ward explicitly thinks is a form of philosophical and biological 'metaphysics'. Panpsychism argues for the presence of 'the protomental' within all levels of the physical world (p. 107). Such a proposal is thoroughly teleological and intentional in its description of material processes, while stopping short of a full-blown Aristotelian notion of 'completion' or 'perfection'. This proposal is tied to teleonomic ideas regarding 'emergence', and advocates a biological proclivity and 'direction' towards 'higher forms of value' while remaining agnostic regarding what such a 'direction' is or means (pp. 108-109). Nevertheless, Ward does not think that it is clear how one can separate such postulations of inherent direction from 'stronger notions of intentionality' and further thinks that 'panpsychic explanations of consciousness' cannot explain how consciousness emerges from matter (p. 109). However, neither does 'creationism' which, so to speak, 'puts the full stop somewhere in the cosmic sentence', exemplifying a kind of 'dualism' which Ward is at pains to exorcize (p. 111), since he is reticent to fill the 'gaps' in our knowledge too hastily with ideas of 'the soul' or 'God'. ${ }^{36}$ Though Ward does not mention it here, this sentiment seems to stem (at least partially) from his theological commitments regarding creation in which God and finite being are not considered be competitive or conflictual since Divine Being is not a 'thing' which can be fitted into some temporalized, causal explanation, but is rather infinite Being itself. 'Creationism', besides being pseudo-scientific, would then also presuppose unorthodox assumptions regarding divine action that are tacitly voluntarist, ontotheological and secularizing since it exemplifies an arbitrary model of divine 'intervention' (along the lines of a late Scholastic model of concursus ${ }^{37}$ ), and because it reduces God to a

35 Cf. Galen Strawson, 'Realistic Monism: Why Physicalism Entails Panpsychism,' in Real Materialism and Other Essays (Oxford: Clarendon, 2008), pp. 53-74.

36 Milbank makes the point however that it is the idea of 'the soul' (combined with a robust, metaphysical account of 'the protophysic' within the physical) that helps to avoid 'dualism' as such. Milbank thinks that the phraseology and debates surrounding the 'mind-matter' question are influenced by certain voluntaristic notions of divine causality. His arguments for this are found in John Milbank, 'The Psychology of Cosmopolitics,' in Resounding the Soul: Reflections on the Metaphysics and Vivacity of the Human Person, eds. Eric Austin Lee and Samuel Kimbriel (Oregon: Cascade Books, 2015), pp. 78-90.

37 Jacob Schmutz, 'The Medieval Doctrine of Causality and the Theology of Pure Nature $\left(13^{\text {th }}\right.$ to $17^{\text {th }}$ Century),' in Surnatural: A Controversy at the Heart of Twentieth-Century 
mere ontic participant in the network of creaturely action (albeit 'larger' in influence and power) and conceives finite being as existing 'extraneously' to divine grace. ${ }^{38}$

Returning again to the theme of 'believability', Ward wants to ask the question how 'beliefs become believable such that we forget they are beliefs - and credit them as truth, as the way things are, as even self-evident and scientific in way that denies (or at least downplays) their association of belief?' (p. 113). It is this drive towards certainty as a non-mediated, sheer diaphanous account of reality that Ward aims to discredit, an account that stems from a refusal to acknowledge the inherently perspectival and valueladen quality of any truth-assertion. It is in this section of Ward's book that we begin to sense some of kind of nascent criteria for judging between varying beliefs as such (as was alluded to earlier). Adopting the language of structuralism, Ward reads the dynamics of believability according to 'synchronic' and 'diachronic' axis of cultural transformation. Ward describes the 'synchronic axis' as relating to the questions of 'authority' and 'authoring' (p. 118) exemplified as 'the normative conditions operating in any culture that support and reinforce the believability of belief' (p. 116). Ward however does not want to create a binary between these two axes, since in any process of cultural capital 'The transformation of believing becomes appreciable when we consider the diachronic axis...it is often in the transformations of believability within the particularities of any given culture that we have access to the synchronic grid that makes believing (and disbelieving) possible (p. 117). Nonetheless, the 'synchronic' can be distinguished as 'the models of knowledge' and 'the epistemological conditions that prevail within any given culture' (p. 121). He goes on to say

The epistemological conditions both determine and are determined by a prevailing anthropology. A conception of what it is to be human involves judgements concerning agency, choice, freedom, judgements related to evaluations of human willing, desiring and the ability to reason. In a culture in which human beings are valued

Thomistic Thought, ed. Serge Thomas-Bonino (Florida: Sapienta Press of Ave Maria University, 2009), pp. 203-250.

38 Cf. John Milbank, The Suspended Middle: Henri de Lubac and the Debate Concerning the Supernatural (Grand Rapids: Eerdmans, 2005); Conor Cunningham, 'Natura Pura, The Invention of the Anti-Christ: A week with no Sabbath,' Communio 37 (Summer 2010): 243-254. 
as being rational above being emotional or imaginative; conceived as being free individuals with a will to choose between various options; recognised as moral agents to the degree that they discipline desire for the sake of duty; respected for their abilities to consider any number of arguments and arrive at a considered judgement of what is the case - then belief is viewed as a weaker form of knowledge, mere opinion. And the patina of the scientific is lent to such knowledge that reasons according to a mathematical calculus concerning the probable. But there are many indications that this anthropology and the epistemological conditions it reinforced - or these epistemological conditions and the anthropology it reinforced - are currently undergoing a major transformation (p. 122).

The 'diachronic axis' points to the fact that 'the objects and expressions of belief change over time' (p. 122) and it is because of these changing objects that 'any synchronic structure that articulates conditional norms for believability has to be supplemented by a diachronic of the temporal contexts which those conditional norms are evident'. These conditional norms are 'abstracted' from their 'temporal contexts' only for 'heuristic' purposes so that they can be modelled. But these objects, however 'abstracted', cannot be immune from the 'cognitive dissonance' that comes as a result in 'the cultural shifts in belief' (p. 123) in which 'the intelligibility of the world is thrown into profound doubt' (p. 125). The idea of objects 'out there' that exist apart from intelligible perception and construction is tied, as Ward says elsewhere, to an 'atomistic' ontology $y^{39}$ and a representationalist epistemology which Ward sees as exemplified by John Locke. ${ }^{40}$ Such a

39 Graham Ward, 'Transcorporality: The Ontological Scandal,' Bulletin of the John Rylands Library 80, no. 3 (1998): 239-241.

40 For Locke, 'All cognitive activity takes place in the receiving and receptive mind. The world is 'out there' and the senses deliver it to us such that the mind becomes a theatre of intellectual representations or ideas of what is out there. The mind 'entertains', and sometimes its ideas connect to what is out there immediately and sometimes they don't. Either way, the epistemological problem is based on the dualism of world and subject (a subject who is like a homunculus operator). Because knowledge is organized in and around this 'problem' of how what goes on in the head hooks up to what is out there in the world, then belief is related to: a) a calculation based on likelihood, itself based on a series of pre-established certainties with which we are familiar; b) the reception of a persuasive argument (and therefore, implicitly, trust in the authority of the supplier of the argument); c) the absence of certain knowledge based upon the immediate relation between idea and thing; d) the absence of 'steps' that might make the 'connection' 
modernist epistemology aspires to a form of knowledge "altogether clear and bright" 41 that is orientated towards 'certainty, transparency, daylight forever; a realised eschatology (without God and without judgement) in which there is no shadow of belief and opinion', aspiring towards what he calls 'angelic truth'. Such knowledge is incarnated in various modernisms, whether it be 'the panopticon' of Bentham, the architecture of Le Corbusier, or the surge of various kinds of religious fundamentalism (p. 130).

In recent critical theory, these forms of knowledge have been deconstructed. However, here drawing again on McGilchrist's work, Ward argues that two forms of believing seem to predominate in the (post)-modern period: the one is a kind of 'acceptance of unknowing or half-knowing and creative ambiguity' (dubbed again as 'right-hemisphere' thinking) and the other is deemed as a thorough-going scepticism in which there is ultimately nothing to know and reality is viewed to be nothing but 'a broken hall of mirrors' (this is believed to a strongly 'left-hemisphere' form of knowing). For Ward, the first form of knowing is open to 'transcending truth', 'empathy' and 'belonging', while the latter tends towards 'fragmentation', 'lack of trust' and 'an over-reliance on the convictions of an isolated subject float upon a world where certainty is no longer possible'. The former is a 'believing in - an object, a relation, and an active commitment - but it cannot be grasped, only lived and participated in' while the latter 'lacks an object, relation or commitment' (pp. 131-132). ${ }^{42}$

There are several points worth mentioning here in light of what we have read: as has been hinted at already, there does seem to be some tacit criterion in this discussion regarding questions of discernment regarding the viability of any particular beliefs. It was earlier remarked that Ward's aim in this book was to expound the idea of belief and believing as such rather than explicitly advocating any particular belief-system. Nonetheless, as Ward

between intuition of the thing and certainty; and e) the separation between the object of belief and that 'which makes me believe" (Unbelievable, pp. 127-28).

41 The phrase is a quote from John Locke's Essay Concerning Human Understanding.

42 One could slightly qualify this statement by saying that nihilism as a form of belief does have an object, albeit nothingness itself, understood as a form of presence (Catherine Pickstock) or a meontological construal of nothing-as-something (Conor Cunningham). One also wonders here whether Ward's implicit preference for 'right-hemisphere' forms of believing leans a bit too much on the left-right hemisphere 'binarism' that he has earlier disavowed. 
will suggest in a later chapter of the book, beliefs can manifest themselves as 'Myths, Lies and Ideology' (pp. 161-186). There he speaks of how myth can be an 'aesthetic' as well as an 'anaesthetic' (p. 162), an ultimately unquestioning immersion in 'false consciousness' (p. 165). Since human beings tend towards 'homeostasis' and a minimum amount of 'cognitive dissonance' for the sake of 'survival', our proclivity is toward maintaining the status quo. Consequently, our mode of 'seeing as' can 'become a seeing as we want to see it' (pp. 168-169). Quoting Roland Barthes, Ward says that mythology can be a way of giving "historical intention a natural justification, and making contingency appear eternal” (p. 174). And when these sentiments are tied to Ward's critique of the secularization thesis (pp. 174-186), it can be seen that Ward's investigation of belief is not blandly neutral but politically charged.

But what are the criteria for making such an adjudication? If any underlying criteria can be gleaned, it would seem (1) that more veridical beliefs are those that express an openness towards otherness and transcendence beyond the reductions of the ego, towards a certain 'resistance' and 'thereness' in reality that is not merely the product of an isolated or collective will. Such a presupposition implies a theory of truthful disclosure in which persons are taken beyond the parochialism of rigid (and sinful?) perspectives towards something like divine 'grace' or 'givenness' (to adopt an explicitly theological frame of reference). In addition to the question of transcendence, there is also (2) the question of time in relation to the processes of belief: those symbolic systems which claim to be 'objective', 'certain' and 'clear', and are thereby 'abstracted' from the historical flux of meaning, loose viability and 'integrity' since what they claim to be asserting (namely, the ultimate truthfulness of their beliefs) is held in tension with the fact that such absolute claims are inextricably tied to political gambits for control and power. ${ }^{43}$ Even though Ward does not put it quite this way, the substance and logic of his arguments imply that any truthful witness involves a vulnerability to change, since we cannot escape the limitations of materiality, and therefore any febrile claim of unchangeability is concerned de facto not with the appearance of truth but with ideological capitulation. Furthermore, as Ward himself argues, the equivalence of 'knowledge' and 'certainty' is by no means a 'necessary'

43 Cf. Rowan Williams, 'Theological Integrity,' in On Christian Theology (Oxford: Blackwell, 2000), pp. 3-15. 
occurrence, but can rather be genealogically traced to certain contingent turns in the intellectual heritage of Western thought, thereby relativizing more strident claims to uphold such equalization. And finally (3), it seems that Ward is advocating the notion that more truthful beliefs are ones that open us to relations of trust, whether that be between differing symbolic communities, or the individuals belonging to such communities (religious or otherwise). Implied within this perspective, is the notion that a less fearbased system of belief enhances a certain embrace of risk in our encounters with the human and cultural other because it is less concerned with egoistic games of rigid identity-formation. Fear drives us towards self-protection, and can therefore (potentially) hinder us from truthful exposure and transformation.

What follows in the remainder of the book is a more substantive filling-in of what Ward actually understands belief to be. Here he uses the example of literature as a mode of 'making believable', a 'making present what is absent' (p. 134). He adduces the Coleridgean notion of 'poetic faith' (pp. 134-137) to show how believing requires a process of imaginative fabrication and 'creation' in order for reality to appear (hereby avowing the representationalist 'objectivism' that he has earlier castigated). Belief is therefore not mere 'expression' but is also 'created' (p. 136). But this creation is not voluntaristic or even necessarily the 'the act of the deliberate will' ${ }^{44}$ because to believe or to 'suspend disbelief' is to be lured by 'the erotic solicitations of the poetic' (p. 136). To believe is 'to be 'engrossed', 'to be absorbed into the world presented' in which 'its world co-evolves with our participation' (p. 139). To be sure this can be a 'morally ambiguous' procedure (p. 136) and Ward is also wants to stress the difference between 'the fictional' and 'the real' (pp. 144-145), and would emphasise strongly that 'poetic faith' is concerned with 'apprehending the irreducibility of

44 Ward is influenced here (at least partially) by Giorgio Agamben's excavations regarding the language of poiesis. Agamben makes the point that the link between 'truth' and 'disclosure' (aletheia) and 'making' (poeisis) was held from early on in philosophical thinking. This is however to be distinguished from another mode of reasoning which, under the influence of certain post-Aristotelian traditions, sought to relate poiesis to ideas regarding the will, a trajectory which reached its apogee in Nietzsche's Wille zur Macht. For these arguments, see Giorgio Agamben, 'Poiesis and Praxis,' in The Man Without Content, trans. Georgia Albert (Stanford; Stanford University Press, 1999), pp. 63-93. 
the real' (p. 157). ${ }^{45}$ Nonetheless, 'the fictional' should not be reduced to 'falsehood' or mere 'fantasy' (p. 208) ${ }^{46}$ since it can bear an 'ontological weight' that has a beneficial effect on our cultural evolution (p. 145). (Such a point was recognized even by Aquinas, despite his suspicion regarding the language of human 'creation' ${ }^{\text {' }}$, since he seems to have allowed a certain mediate actuality to the realm of 'the fictional'.48) Moreover, the realm of 'imagination' can lead us to an 'expansion' of our 'material limitations' and 'belief structures' (p. 147), thereby opening us, potentially, to 'the critique and transformation of the social status quo' (p. 151). This tapestry of projection and desire is inextricably woven together with 'the practice of hope' (pp. 152-155), in which we are able to go 'beyond what is available' towards an as-of-yet invisible 'horizon' of imagined anticipation (p. 152) a concept Ward will later summarize as a form 'transcendental freedom' (p. 199).

The theme of 'invisibility', that is hinted at throughout the study, comes to the fore especially in the final chapter, in which Ward evokes the language of 'faith' in a manner that explicitly ties his account to Judeo-Christianity, in which we are exhorted (cf. Romans 1 and Hebrews 11) to 'live from what is unseen to what is unseen' (p. 186). In accord with his more general thesis, 'religious faith' for Ward should be understood as 'a specific orientation of a more primordial disposition to believe' (p. 219). Ward reiterates again that 'belief' as a 'dispositional' reality is universal, but our more primordial dispositions and beliefs are further thematised, within explicit religiosity,

45 Ward clarifies this later in the book: 'Perceptions arise because there is a real world of objects out there, and the scenarios we construct are not mere fantasies. We are social animals so the worlds we construct are shared worlds. We continually modify the world-patterns we make in association with other human beings engaged in the same activity. Our world-making is always in negotiation with other world-making; we are continually undergoing a form of persuasion that this is the true, the real, the way things are. If we remain unpersuaded, then we experience anxiety and become hesitant and undecided. The mental patterns do not form, or form only incoherently' (Unbelievable, p. 206).

46 'Fantasy is not self-transcending. It is a form of self-idolatry, for it begins and ends with projection: the screening of a narrative in which the ego is always at the centre of the plot. Such fantasies, like evil and sin, have no ontological weight - they are acts of decreation or non-being' (Unbelievable, p. 208).

47 Cf. Robert C. Miner, Truth in the Making: Creative Knowledge in Theology and Philosophy (London: Routledge, 2004), pp. 1-18.

48 John Milbank, 'On 'Thomistic Kabbalah', Modern Theology 27, no.1 (2011): 147-185. Milbank is drawing heavily here on the work of Olivier-Thomas Venard. 
as 'a confession of an unseen above and beyond the unseen that pertains to the practices of everyday life' (p. 189). The latter move implies a particular response and construal of the 'invisible in the visible' since 'The invisible is a property of the visible' (p. 190) and all readings of such invisibility inescapably imply some mode of 'interpretation' (p. 192) and a 'special commitment', which while not resulting in 'a different type of believing' ${ }^{49}$ are nonetheless enframed within the particular 'perception' of religious practice (p.220). Ward dubsthis inescapability of value-laden 'interpretation' (religious or otherwise) as 'perspectival invisibility', a phrase that aims to condense that 'There is no view from nowhere', that 'there is always an invisibility that pertains to the visible and partial that we do see' (p. 192). Ward is inspired here by Merleau-Ponty's idea of 'la foi perspective' (p. 196) by which he sought to account for the value-laden quality of perceptual experience as an invisibility-within-the-visible, a meaningfulness that inheres within the world of things. Since the world of objects cannot be separated from such invisibility but (on the contrary) is 'saturated' with it, Ward probes Merleau-Ponty further regarding the directionality of this saturation, with the purpose of showing that this unfolding invisibility and ever-deepening unpresentablity 'cannot be divorced from or pitted against a construal of an absolute transcendent' (p. 197). Ward's apparent intention here is to push Merleau-Ponty's phenomenology towards a theological form of transfinite disclosure, an 'intentional transcendentalism' ( $p$. 199) in which the physical realm is orientated towards an ontological 'givenness' that exceeds the merely 'given', in the direction of a 'grace' that moves beyond and perfects the natural order. One could further describe this reality as a divine invisibility (pp. 200-201) that is 'operative within what is materially visible' (p. 221), a transcendent 'exteriority'50 that is intelligible and open to the free 'recognition' of finite and sensible human beings (pp. 214-217). All this sounds like an account of revelation (albeit non-dualistic, and post-Barthian). Furthermore, this vision of truthful perception of the transcendent within the finite seemingly cannot avoid

49 One wonders whether this phraseology helps Ward bring across the real differences between the orders of believing. Analogous as they may be, the deeper intensity of religious commitment is a sine qua non. More clarity would have been desirable here.

50 Ward distinguishes this 'exteriority' from 'pure' or 'objective' exteriority since, as he has repeated numerously, we only ever perceive as something, and therefore cannot speak of 'things in themselves' (Unbelievable, p. 214). The Kantian references here are again explicit. 
reference to the 'analogical' and the irreducible apophasis that remains between 'human scientia and divine knowledge'; a 'gap' that ultimately remains 'unbridgeable for us' but at the same time 'opens up the greatest of all space of possibles' in which 'we point ahead of ourselves, into what is hidden in the invisibility, into the heart of believing itself' (p. 221).

At the end of Ward's ambitious and multidisciplinary work, one feels enlightened regarding the workings of 'belief' within its myriad interconnections. After digesting this volume (which is the first in a projected series, with one soon to follow), there is a sense of having one's vision expanded to see the phenomenon of 'belief' within an intricate panoply of ever-expanding participation within the hierarchy of being. Even though he does not expand significantly upon this contention here, it seems to be an informing assumption within this work, and one that is unpacked in the detail of the argument. Despite the explicitly nonconfessional nature of the book, Ward has grounded his phenomenology of belief in a metaphysical depth-structure that tries to avoid the asseveration of culture from the material orders, rendering lucid the entwinement of belief with the natural. As has been mentioned throughout, this is part of Ward's attempt to counteract the philosophical dualisms that continue to impede our comprehension of the world. And yet further, this move appears also to be a manifestation (more surreptitiously) of his beliefs regarding theological 'integralism', acting as a subtle plea (within largely non-theological language) for an analogical participation of the visible in the invisible, in a trans-dimensional actuality that both transcends and includes the transcended within its alluring opacity.

In conclusion, and in a more critical vein, one would have liked to see a bit more detail regarding the ontological import of the different levels of believing, namely (1) belief as a generalized disposition and (2) belief as an explicitly religious practice. Ward's focus is largely is on the former, a move which could lead (incorrectly) to the impression that Ward is basically a liberal at heart, advocating a nebulous ocean of believing, with particular faiths being merely rivulets finally streaming us to same, univocal source. That such an impression is possible can be gleaned from the fact that Ward has to defend himself against such a claim at the end of the book where he says (apropos Tillich's notion of 'ultimate concern') that Tillich failed to account for the complexity and inherent diversity of 'religious experience' 
(p. 220). But on Ward's part, more should have been said in this regard since any attempt to reduce religions to some generalized, common denominator of 'belief' remains unsatisfactory for any religious practitioner. Even the characteristic of 'belief' is non-universalizable from within a religious perspective. ${ }^{51}$ Such a procedure could potentially assume an outsiders' perspective that tacitly claimed a superior vantage of judgement, able to parse-out the essential 'faith' lying behind local and cultural accretions. I don't believe Ward makes this move. And furthermore, it seems that from within the trajectory of Ward's argument, there is a way to address this question. For beyond his grounding of 'belief' in the fundamental and quotidian realities of life, it would have been quite easy to tease out further the deeper foundations for tradition and ritual within human culture within the model he was advancing. This would have further strengthened his argument regarding the embeddedness of belief-systems, and would have also rendered limpid the profound basis for religious specificity ${ }^{52}$ and the 'strangeness' of custom ${ }^{53}$ within the very stuff of material interaction. Here the category of 'habit' ${ }^{54}$ as 'non-identical repetition's5 might have been useful for his purposes; it would also would have segued nicely with overall subtext and tenor of the book, since it could have deepened the tradition of philosophical 'spiritualism' and 'vitalism' that inspired French phenomenological thinking (De Biran, Ravaisson, Bergson, etc.), which (as has been shown above) is essential for Ward's argumentation.

51 Talal Asad, 'Thinking about Religion, Belief, and Politics,' in The Cambridge Companion to Religious Studies, ed. Robert A. Orsi (Cambridge: Cambridge University Press, 2012), pp. 36-57. Also cf. Tomoko Masuzawa, The Invention of World Religions: Or How European Universalism Was Preserved in the Language of Pluralism (Chicago: Chicago University Press, 2005).

52 Cf. Pickstock, The Ritual Birth of Sense'.

53 'Custom is strange.../ not least in its familiar power of estrangement,' in Geoffrey Hill, 'The Triumph of Love, CXXV', in Broken Hierarchies: Poems 1952-2012, ed. Kenneth Haynes (Oxford: Oxford University Press, 2013), p. 276.

54 Félix Ravaisson, Of Habit, trans. Clare Carlisle and Mark Sinclair (London and New York: Continuum, 2008); John Milbank, 'The Mystery of Reason,' in The Grandeur of Reason: Religion, Tradition and Universalism, in eds. Conor Cunningham and Peter M. Candler Jr (Great Britain: SCM, 2010), pp. 102-115.

55 Catherine Pickstock, Repetition and Identity. The Literary Agenda (Oxford: Oxford University Press, 2013). 
And finally, it would be good for Ward to clarify his appropriation of Kantian philosophy. Clearly (as in his discussion of Locke) he has problems with representationalist and 'objectivizing' epistemologies, and he also bemoans the Cartesian and Kantian biases of modern neuroscience (cf. p. 207). He also is clearly critical of post-Kantian modes of 'phenomenological reduction' in which the immanent is bracketed apart from transcendent meaning. He also takes issue with Kant's separation of faith and knowledge. ${ }^{56}$ But in his positive appropriation of Kant's agnosticism regarding the Ding-an-Sich, is Ward reading Kant's theory of knowledge apart from its inherent ontological consequences? Kant understood his own project to be the 'humble' substitution of 'ontology' for a 'transcendental analytic' of 'pure understanding', with the noumenon being effectively 'nothing for us' part from the confines of 'sensibility'. ${ }^{57}$ But does this assumption not leave out of account the recent criticisms of such 'correlationist' thinking ${ }^{58}$, or the post-Hegelian critiques of such 'humility' in which '[pure] reason so unambiguously (and dubiously)' is 'able to specify its own limits [and] in this way transgresses them in doing so, simultaneously both by speciously separating the empirical from the abstract and by predetermining the limits of the transcendence it has foresworn'. ${ }^{59}$ Based on these points, it can be suggested that while Kant does not seem to be determinative for Ward's approach, it would be helpful for him to clarify his own reception of the Kantian tradition in his future work. However, since Kant does not play a significant role in this study, these criticisms do not really touch upon the kernel of his argument.

And so at the end of this work, and emerging from Plato's cave so to speak, we have been lured again by the play of shadowy forms upon the hardened skin of the world, a world in which 'surfaces need not be superficial'60

56 Cf. Immanuel Kant, The Critique of Pure Reason, trans. Paul Guyer and Allen Wood (Cambridge: Cambridge University Press, 1998), Bxxx.

57 Kant, The Critique of Pure Reason, A235-259; B294-315.

58 Quentin Meillassoux, After Finitude: An Essay on the Necessity of Contingency, trans. Ray Brassier (London and New York: Continuum, 2008).

59 Hanby, 'Review: God, The Mind's Desire,' 308-309. Also, cf. Conor Cunningham, Genealogy of Nihilism: Philosophies of Nothing and the Difference of Theology (London and New York: Routledge, 2002), pp. 74-99.

60 W. H. Auden, 'Good-Bye to Mezzogiorno (For Carlo Izzo),' in Collected Shorter Poems: 1927-1957 (London: Faber and Faber, 1966), p. 340. 
towards a 'horizon' where 'the whole prevails over its parts, and things become beings again'. ${ }^{61}$

\section{Bibliography}

Agamben, Giorgio, "Poiesis and Praxis," in The Man Without Content, trans. Georgia Albert (Stanford; Stanford University Press, 1999), pp. 63-93.

Asad, Talal, 'Thinking about Religion, Belief, and Politics,' in The Cambridge Companion to Religious Studies, ed. Robert A. Orsi (Cambridge: Cambridge University Press, 2012), pp. 36-57.

Auden, W. H., Collected Shorter Poems: 1927-1957 (London: Faber and Faber, 1966).

Baudrillard, Jean, Simulations, trans. Phil Beitchman et al. Semiotext[e] (Cambridge: MIT Press, 1983).

Bonnefoy, Yves, Second Simplicity: New Poetry and Prose, 1991-2011, trans. Hoyt Rogers (New Haven and London: Yale University Press, 2011).

Bourdieu, Pierre, "The Production of Belief: Contribution to an Economy of Symbolic Goods," in The Field of Production: Essays on Art and Literature, ed. Randal Johnson (New York: Columbia University Press, 1993), pp. 74-111.

Brugère, Fabienne, "Common Sense," in Dictionary of Untranslatables:

A Philosophical Lexicon, ed. Barbara Cassin (Princeton and Oxford:

Princeton University Press, 2014), pp. 152-154.

Cassin, Barbara et al, "Sense / Meaning," in Cassin, Dictionary of Untranslatables, pp. 949-967.

61 Yves Bonnefoy, 'Remarks on the Horizon,' in Second Simplicity: New Poetry and Prose, 1991-2011, trans. Hoyt Rogers (New Haven and London: Yale University Press, 2011), p. 219. 
Certeau, Michel de, The Mystic Fable: The Sixteenth and Seventeenth Centuries, vol. 1, trans. Michael B. Smith (Chicago: Chicago University Press, 1995).

- The Possession of Loudun, trans. Michael B. Smith (Chicago: Chicago University Press, 2000).

Chrétien, Jean-Louis. The Call and the Response, trans. Anne Davenport (New York: Fordham University Press, 2004).

Coakley, Sarah, God, Sexuality, and the Self: An Essay 'On the Trinity' (Cambridge: Cambridge University Press, 2013).

Cunningham, Conor, Genealogy of Nihilism: Philosophies of Nothing and the Difference of Theology (London and New York: Routledge, 2002).

- "Natura Pura, The Invention of the Anti-Christ: A Week With No Sabbath," Communio 37 (Summer 2010): 243-254.

- Darwin's Pious Idea: Why Ultra-Darwinists and Creationists Both Get It Wrong (Grand Rapids: Eerdmans, 2010).

Debord, Guy, The Society of the Spectacle, trans. Ken Knabb (London: Rebel Press, 1992).

De Libera, Alain. "Sensus Communis," in Cassin, Dictionary of Untranslatables, 967-968.

De Muralt, André, “The 'Founded Act' and The Apperception of Others: The Actual Scholastic Sources of Husserlian Intentionality. An Essay in Structural Analysis Of Doctrines," in Analecta Husserliana: The Yearbook Of Phenomenological Research, vol. VI, ed. Anna-Teresa Tymieniecka (Dordrecht: Springer, 1977), pp. 123-141.

Esposito, Constantino, „Die Schranken der Erfahrung und die Grenzen der Vernunft: Kants Moraltheologie“. Aufklärung 21 (2009): 117-145.

Fuchs, Thomas, "Overcoming Dualism," Philosophy, Psychiatry, \& Psychology 12, no. 2: 115-117.

Hanby, Michael. "Review: God, The Mind's Desire: Reference, Reason and Christian Thinking by Paul D. Janz," Modem Theology 22, no. 2 (2006): 307-309.

Hill, Geoffrey. Broken Hierarchies: Poems 1952-2012, ed. Kenneth Haynes (Oxford: Oxford University Press, 2013). 
Kant, Immanuel, The Critique of Pure Reason, trans. Paul Guyer and Allen Wood (Cambridge: Cambridge University Press, 1998).

Janz, Paul D., God, the Mind's Desire: Reference, Reason and Christian Thinking (Cambridge: Cambridge University Press, 2004).

Lear, Jonathan, Aristotle: The Desire to Understand (Cambridge: Cambridge University Press, 1988).

MacKinnon, Donald, "Kant's Agnosticism," in Philosophy and the Burden of Theological Honesty: A Donald MacKinnon Reader, ed. John McDowell. (London and New York: T \& T Clark, 2011), 27-34.

- “Kant's Philosophy of Religion,” Philosophy 50, no. 192 (1975): 131-144.

Masuzawa, Tomoko, The Invention of World Religions: Or How European Universalism Was Preserved in the Language of Pluralism (Chicago: Chicago University Press, 2005).

Meillassoux, Quentin, After Finitude: An Essay on the Necessity of Contingency, trans. Ray Brassier (London and New York: Continuum, 2008).

Milbank, John, "A Critique of the Theology of Right," in The Word Made Strange: Theology, Language, Culture (Oxford: Blackwell 1997), pp. 7-35.

- "The Soul of Reciprocity, Part Two: Reciprocity Granted," Modern Theology 17, no. 4 (2001): 485-507.

- The Suspended Middle: Henri de Lubac and the Debate Concerning the Supernatural (Grand Rapids: Eerdmans, 2005).

- Theology and Social Theory: Beyond Secular Reason ( $2^{\text {nd }}$ ed. Oxford: Blackwell, 2006).

- 'The Thomistic Telescope: Truth and Identity.' American Catholic Philosophical Quarterly 80, no. 2 (2006): 193-226.

- "On the Diagonal: Metaphysical Landscapes," in The Legend of Death: Two Poetic Sequences (Eugene, Oregon: Cascade Books, 2008), pp. 2-7.

- "The Mystery of Reason," in The Grandeur of Reason: Religion, Tradition and Universalism, in eds. Conor Cunningham and Peter M. Candler Jr (Great Britain: SCM, 2010), pp. 102-115.

- "On “Thomistic Kabbalah", Modern Theology 27, no. 1 (2011): 147-185. 
- "The Psychology of Cosmopolitics," in Resounding the Soul: Reflections on the Metaphysics and Vivacity of the Human Person, eds. Eric Austin Lee and Samuel Kimbriel (Oregon: Cascade Books, 2015), pp. 78-90.

Milbank John and Pickstock, Catherine, Truth in Aquinas (London and New York: Routledge, 2001).

Miner, Robert C., Truth in the Making: Creative Knowledge in Theology and Philosophy (London: Routledge, 2004).

Gilbert Narcisse, O.P. “Thomistic Realism?” Nova et Vetera, English Edition 8, no. 4 (2010): 783-798.

Pickstock, C. J. C., “The Ritual Birth of Sense,” Telos 162 (Spring 2013): 29-55.

Pickstock, Catherine, Repetition and Identity. The Literary Agenda (Oxford: Oxford University Press, 2013).

Pieper, Josef, The Silence of St. Thomas: Three Essays (London: Faber \& Faber, 1957).

Prynne, J. H., Stars, Tigers and the Shape of Words (London: Birkbeck, 1993).

- "Poetic Thought," Textual Practice 24, no. 4 (2010): 595-606.

Schmutz, Jacob, "The Medieval Doctrine of Causality and the Theology of Pure Nature (13 $3^{\text {th }}$ to $17^{\text {th }}$ Century)," in Surnatural: A Controversy at the Heart of Twentieth-Century Thomistic Thought, ed. Serge ThomasBonino (Florida: Sapienta Press of Ave Maria University, 2009), pp. 203-250.

Sellars, Wilfrid, "Empiricism and the Philosophy of Mind," in The Foundations of Science and the Concepts of Psychology and Psychoanalysis. Minnesota Studies in the Philosophy of Science, vol. I, eds. Herbert Feigl and Michael Scriven (Minneapolis: University of Minnesota Press, 1956), pp. 253-329.

Stevens, Wallace, Collected Poems (London: Faber and Faber, 1984).

Strawson, Galen, "Realistic Monism: Why Physicalism Entails Panpsychism," in Real Materialism and Other Essays (Oxford: Clarendon, 2008), pp. 53-74. 
Ward, Graham, "Transcorporality: The Ontological Scandal," Bulletin of the John Rylands Library 80, no. 3 (1998): 239-241.

- "The Logos, the Body and the World: On the Phenomenological Border," in Transcending Boundaries in Philosophy and Theology, eds. Kevin Vanhoozer and Martin Warner (Aldershot and Burlington: Ashgate, 2007), pp. 105-126.

- The Politics of Discipleship: Becoming Postmaterial Citizens (Grand Rapids: Baker Academic, 2009).

- "Affect: Towards a Theology of Experience," Radical Orthodoxy: Theology, Philosophy, Politics 1, no. 1-2 (2012): 55-80.

- "The Myth of Secularism," Telos 167 (Summer 2014): 162-79.

- "Salvation: The Pedagogy of Affect," Nederduits Gereformeerde Tydskrif Supplement 1 (2014): 999-1013.

- Unbelievable: Why We Believe and Why We Don't (London \& New York: I. B. Tauris, 2013).

- How the Light Gets In: Ethical Life I (Oxford: Oxford University Press, 2016).

Williams, Rowan, "Poetic and Religious Imagination,” Theology 80 (1977): 178-187.

- "Theological Integrity," in On Christian Theology (Oxford: Blackwell, 2000), pp. 3-15.

- Grace and Necessity: Reflections on Art and Love (London and Harrisburg: Continuum, 2005).

- The Edge of Words: God and the Habits of Language (London: Bloomsbury, 2014). 